\title{
LEDERPLATTFORM
}

$\mathbb{1}$ Nordisk ministerråd

(2) 


\section{LEDERPLATTFORM FOR NORDISK MINISTERRÅD}

ISBN 978-92-893-4865-2 (PRINT)

ISBN 978-92-893-4866-9 (PDF)

http://dx.doi.org/10.6027/ANP2017-710

ANP 2017:710

(c) Nordisk ministerråd 2017

Layout: Louise M. Jeppesen

Foto: Ricky John Molloy

Trykk: Rosendahls

Printed in Denmark

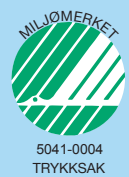

\section{Det nordiske samarbeidet}

Det nordiske samarbeidet er en av verdens mest omfattende regionale samarbeidsformer. Samarbeidet omfatter Danmark, Finland, Island, Norge og Sverige samt Færøyene, Grønland og Åland. Det nordiske samarbeidet er både politisk, økonomisk og kulturelt forankret, og er en viktig med-spiller i det europeiske og internasjonale samarbeid. Det nordiske fellesskapet arbeider for et sterkt Norden i et sterkt Europa. Det nordiske samarbeidet ønsker å styrke nordiske og regionale interesser og verdier i en global omverden. Felles verdier landene imellom bidrar til å styrke Nordens posisjon som en av verdens mest innovative og konkurransekraftige regioner.

\section{Nordisk ministerråd}

Ved Stranden 18

DK-1061 København K www.norden.org 


\title{
LEDERPLATTFORM
}

for Nordisk ministerråd

\author{
Innhold
}

FORORD 5

LEDERVERDIER 6

DIMENSJONER I LEDELSE 8

OPPDRAGET 11

BILAG -

Spilleregler i ledelse -

praktisk del

Lederstrukturen i

Nordisk ministerråd

15

Lederrollene

15

Den utvidede ledergruppen

16

Ledergruppen ved NMRS

16

Samarbeidet med personal-

organisasjoner

17

Hvordan plattformen bør brukes

17 


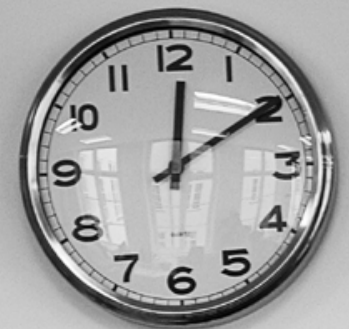

Reykjavík

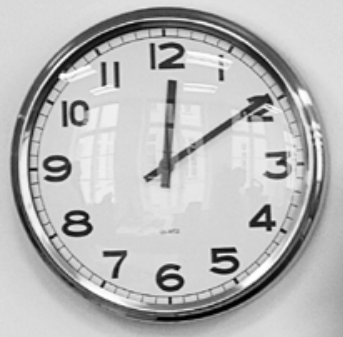

Tórshavn

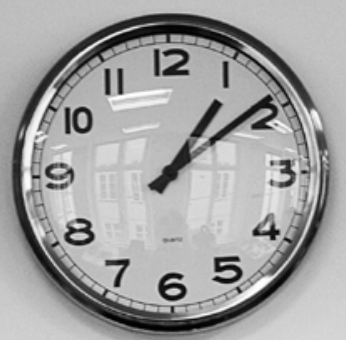

Oslo

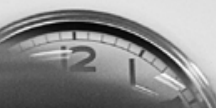

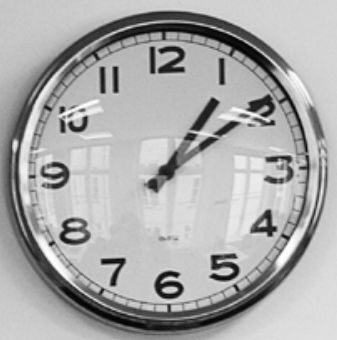

Stockholm

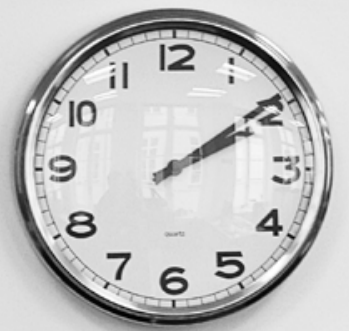

Mariehamn

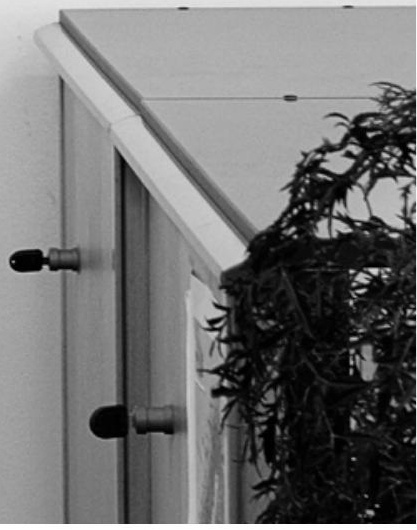




\section{FORORD}

I lederplattformen presenteres de grunnleggende kravene til - og normene for - ledelse i Nordisk ministerråd. Plattformen omfatter ledere i Nordisk ministerråds sekretariat, kontorsjefer og institusjonssjefer.

Plattformen bygger på de styrende dokumentene for Nordisk ministerråds arbeid, men også på hva som generelt betraktes som god forvaltningsskikk og godt lederskap. Plattformen har tre pilarer:

- Lederverdier

- Dimensjoner i ledelse

- Oppdraget
Plattformen er ikke uttømmende, men angir en rekke hovedprinsipper og en retning som hver enkelt leder skal følge. Dette innebærer også at den enkelte medarbeider kan forvente at ledelse blir utøvd i tråd med lederplattformen, men det skal også være rom for individuelle lederstiler.

København 16. februar 2017

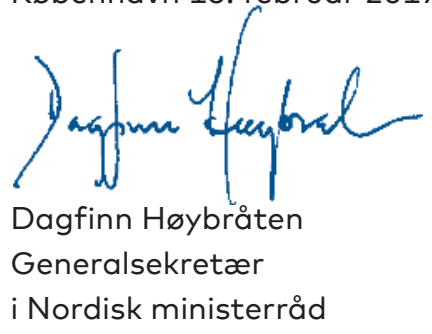

Som bilag til plattformen finnes avsnittet Spilleregler i ledelse, som inneholder mer praktiske spørsmål knyttet til ledelse i Nordisk ministerråd. 


\section{LEDERVERDIER}

Som ledere formidler vi Nordisk ministerråds verdier både når vi utøver ledelse internt og når vi opptrer eksternt. Som ledere skal vi være forbilder ved at det vi står for, stemmer overens med det vi gjør. Våre lederverdier kan sammenfattes slik:

\section{Vi er tydelige og troverdige}

Vi sier hva vi gjør, og vi gjør det vi sier.

Vi kommuniserer klart og tydelig.

Vi er bevisste på at vi gjennom vår atferd viser organisasjonens ansikt.

\section{Vi fremmer samarbeid}

Vi løser gjerne oppgaver i fellesskap og bruker alles kompetanse.

Vi fremmer samarbeid på tvers $\mathrm{i}$

Nordisk ministerråd og mellom

forskjellige fagområder.

Vi prioriterer sparring og kunnskapsdeling.

\section{Vi prioriterer og skaper resultater}

Vi fokuserer på resultater som gir stor merverdi for de nordiske landene. Vi prioriterer det som er viktig, og avklarer hva som er mindre viktig.
Vi fastsetter felles mål, ser muligheter og håndterer risiko.

Vi fremmer effektiv oppgaveløsning.

Vi har alle et ansvar for helheten.

\section{Vi respekterer og har tillit til} hverandre

Vi har tillit til og lytter til den enkelte. Vi bruker medarbeidernes ulikhet til å utvikle kompetansen i organisasjonen.

\section{Vi fremmer motivasjon, engasje-} ment og arbeidsglede

Vi skaper en arbeidsplass der initiativ og samarbeid verdsettes.

Vi har fokus på å engasjere den enkelte medarbeider i å skape resultater.

\section{Vi fremmer mangfold og inkludering Vi fremmer like rettigheter og mulig- heter for alle medarbeidere.}

Allerede ved rekrutteringen går vi ut fra et arbeidsliv/arbeidsfellesskap som arbeider for mangfold og inkludering, og der personer vurderes ut fra sin kompetanse. 


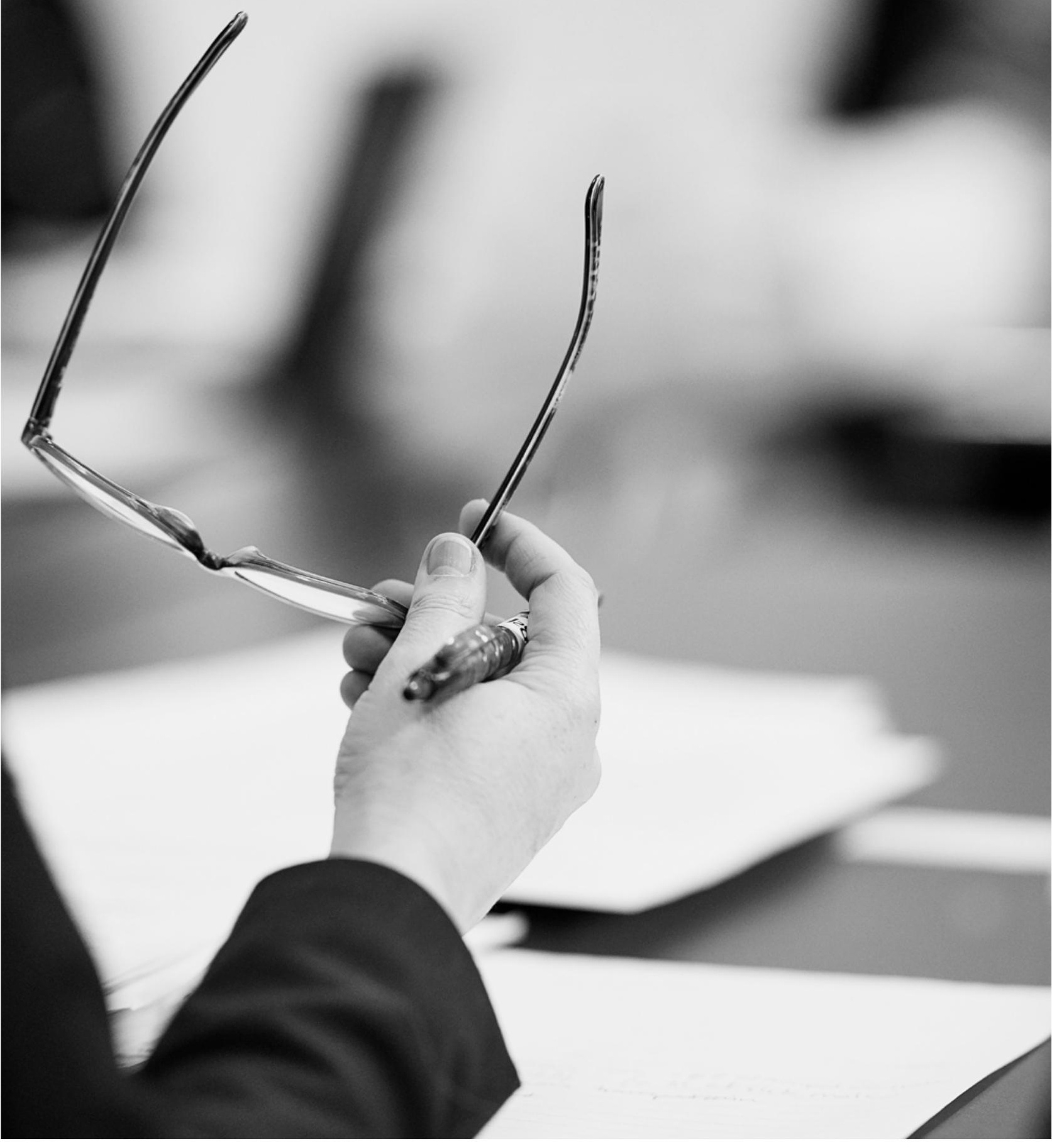




\section{DIMENSJONER I LEDELSE}

En måte å beskrive ledelse på, er å se på begrepet i følgende dimensjoner:

Fag

Lederens profesjon og faglige ansvarsområde osv.

\section{Planlegging, administrasjon}

\section{og styring}

Strategier, planlegging, drift, organisering, administrativ kontroll, oppfølging, evaluering, modernisering, effektivisering, fornyelse osv.

\section{Relasjon til medarbeiderne (ledelse)}

Motivere, veilede, støtte, håndtere konflikter, bidra til utvikling osv.

Disse dimensjonene virker $\mathrm{i}$ et samspill på et fundament av kommunikativ ledelse. Å lede handler i stor grad om å skape resultater gjennom og sammen med sine medarbeidere. Ofte besitter medarbeiderne en bedre fagkompetanse enn lederen.
Vi skal utøve en helhetlig og enhetlig, verdibasert og kommunikativ samt utviklings- og medarbeiderfokusert ledelse. Med det mener vi følgende:

Helhetlig og enhetlig ledelse: Lederne skal sikre at de ulike delene og nivåene av organisasjonen ser sine oppgaver som en del av helheten. Helhetstenkningen skal gjennomsyre arbeidsformer, saksbehandling og løsningsforslag i alle ledd i organisasjonen. Vi skal også lede våre medarbeidere på en enhetlig måte, slik at alle medarbeidere kan kjenne igjen de samme prinsipper og verdier hos alle ledere.

Verdibasert ledelse: Sentralt i ledelsen står det enkelte menneskes verdi. A ta mennesker på alvor, lytte, respektere og tolerere er viktige sider av dette. Det betyr også at lederne skal fungere som rollemodeller for de verdiene og holdningene som organisasjonen baserer sin virksomhet på. 
Kommunikativ ledelse: $\AA$ lede handler i veldig stor grad om å kommunisere. Tydelig kommunikasjon forutsetter at lederne vet hva de vil, og har mot til å by på seg selv. En leder i Nordisk ministerråd tar aktivt ansvar for kommunikasjonen i forhold til medarbeidere og kollegaer og også eksterne samarbeidspartnere og interessenter.

Utviklingsorientert ledelse: Organisasjonen skal være åpen for læring, utvikling og nytenkning. Viljen til endring er avgjørende for evnen til å yte. Ledelse er det motsatte av status quo, og ledere skal ha et kontinuerlig fokus på forbedringer. En leder skal være proaktiv og nysgjerrig og se mulighetene. Vi skal ta initiativ, framheve potensialet i det nordisk samarbeidet og fremme løsninger basert på kunnskap.
Medarbeiderfokusert ledelse: Dette innebærer at man som leder tar ansvar for å bidra til medarbeidernes vekst og utvikling samt gir dem handlingsrom og ansvar i tillegg til verktøyene og rammeforutsetningene som setter dem i stand til å utføre sitt arbeid på best mulig måte. I dette ligger også et spesielt ansvar for å rekruttere medarbeidere med god og riktig kompetanse. 


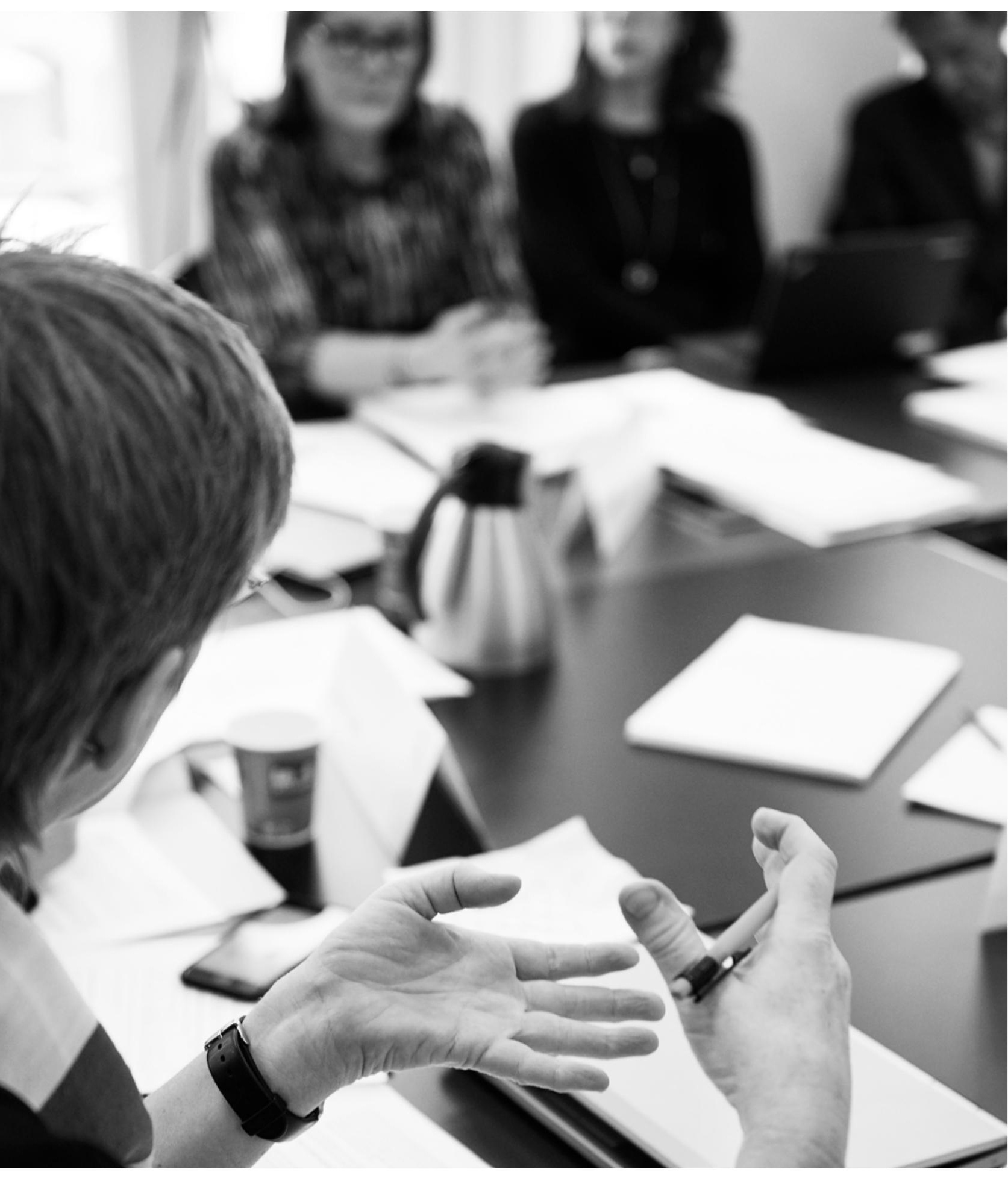




\section{OPPDRAGET}

En leder har det fulle ansvaret for alt som skjer innenfor sitt område. Man kan selvsagt delegere det praktiske ansvaret for arbeidsoppgavene, men lederen står like fullt organisatorisk ansvarlig for resultatet.

Med delegering menes å gi ansvar for oppgaver og nødvendig myndighet til å løse disse. Å veilede, rette, stille krav til resultatet og følge opp medarbeiderne går hånd i hånd med å delegere.

En leder i Nordisk ministerråd har et spesielt ansvar for:

Å nå oppsatte mål som er i samsvar med politiske og administrative beslutninger (resultatansvar) Ved hjelp av ulike planleggings- og styringsverktøy skal lederne sette opp klare mål for virksomheten, definere krav til resultat, og sammen med medarbeiderne realisere målene. Lederen har budsjettansvar for sin virksomhet, dvs. ansvar for å foreslå omfanget av budsjettet og ansvar for å holde det. Lederne er også rådgivere for generalsekretæren og iverksetter politiske og administrative vedtak.
Å bidra til forbedring, fornyelse, effektivisering og omstilling med sikte på å nå langsiktige mål for det nordiske samarbeidet mellom landenes regjeringer Den enkelte leder skal ha et kontinuerlig fokus på forbedringer innenfor sitt eget område og i det nordiske samarbeidet som sådan.

Å utvikle selvstendighet, ansvarsfølelse og kompetanse hos medarbeiderne Lederen må kontinuerlig vurdere og utvikle medarbeidernes kompetanse og sørge for at den blir brukt optimalt. Gjennom delegering, organisering, fordeling og prioritering av arbeidsoppgavene og positiv oppfølging skal lederen stimulere den enkelte medarbeider til gode resultater. Ved hjelp av alle medarbeiderne skal lederen skape entusiasme og motivasjon for målene som skal nås. Lederens personalansvar innebærer også at han eller hun skal vise omsorg for de ansatte ved aktivt å fremme et godt arbeidsmiljø med trygghet, takhøyde, trivsel og utvikling for den enkelte medarbeider. Innenfor en slik ramme skal en leder også utfordre sine medarbeidere og stille klare krav samt sørge for at medarbeiderne 
også tar et ansvar for å gi tilbakemeldinger til sin nærmeste leder om hvordan ledelsen utøves.

\section{Å representere arbeidsgiver og utøve god personalledelse}

Lederen har et delegert arbeidsgiveransvar for sitt personale. Dette er en del av det totale resultatansvaret lederen har. Sammen med de ansatte skal lederen følge gjeldende personalpolitikk, etiske regler og habilitetsregler. Lederen skal utøve gode arbeidsgiverholdninger som blant annet betyr lojalitet til aktuell fastsatt politikk og beslutninger med konsekvenser for personalet.

\section{Å integrere kommunikasjon og informasjon i sitt linjeansvar} Informasjon og kommunikasjon, internt og eksternt, er et viktig verktøy for å nå resultatmålene. En leder skal holde seg godt orientert også utenfor eget ansvarsområde, samt sørge for at informasjon tilflyter de som har nytte av den. Gjennom informasjon og kommunikasjon bidrar lederne til økt synlighet og kunnskap om det nordiske samarbeidet.

\section{Å representere virksomheten utad} En leder innenfor Nordisk ministerråd er godt oppdatert på omverdenen og skal på beste måte profilere virksomheten utad. Lederne skal være spesielt bevisst på at de skal opptre som gode representanter/ambassadører for Nordisk ministerråd $i$ enhver sammenheng, og at de ved dette er med på å forme vårt omdømme.

Å utvikle seg selv som leder Lederen skal ha et kontinuerlig fokus på å utvikle seg selv i alle dimensjonene i ledelse, både innenfor og utenfor sitt ansvarsområde. Å utvikle seg selv som leder kan skje på et individuelt plan, men også sammen med medarbeidere eller som et ledd i utviklingen av ledergruppen.

Å være lojal

Enhver leder har et lojalitetsansvar overfor sin oppdragsgiver og sitt oppdrag. I vår organisasjon innebærer det blant annet et lojalitetsforhold til nærmeste leder, til medarbeiderne, til ledergruppen, til ministerrådet, til embetsmannskomiteene og til landene. 
Lederne skal også være lojale mot målene og regelverket som er satt for Nordisk ministerråds virksomhet, herunder mot denne lederplattformen. Kommer man i noen form for lojalitetskonflikt, bør man ta dette opp med sin nærmeste leder.

Lederne har et spesielt ansvar for å ta opp venighet og misnøye direkte med den det gjelder, og ikke med andre eller via andre.

$\AA ̊$ være lojal innebærer en forventning om konstruktiv deltakelse. I beslutningsprosessene skal, så langt som mulig, alle berørte personer delta. Vi vil ha åpne og inkluderende beslutningsprosesser der takhøyden er stor. Enhver leder og medarbeider har rett og plikt til å fremme de synspunkter man mener er viktige og sørge for at alle relevante aspekter er kjent før beslutninger fattes. Når en beslutning er fattet, skal man lojalt følge og forsvare denne, også om man er venig i beslutningen. Skjulte og personlige agendaer er ikke forenlig med lojalitet.
Å utvise kollegialitet

Ledere skal utvise kollegialitet. Til grunn for dette ligger tillit og respekt for hverandres kompetanse, ansvar og resultater. Det betyr å dele relevant informasjon og å involvere andre ved behov. Det innebærer også en åpenhet for gjensidig støtte, omsorg og kritikk. Kritikk av kollegaer skal rettes direkte til den det gjelder, og den skal være konstruktiv. Den gjensidige støtten mellom ledere er basert på at lederne er et kollegium der alle opptrer solidarisk overfor hverandre og har et medansvar for å bidra til styring og utvikling av den samlede virksomheten.

Enhver leder skal kjenne et medansvar for at lederkollegaene skal lykkes, men også for å gi støtte i motgang. 


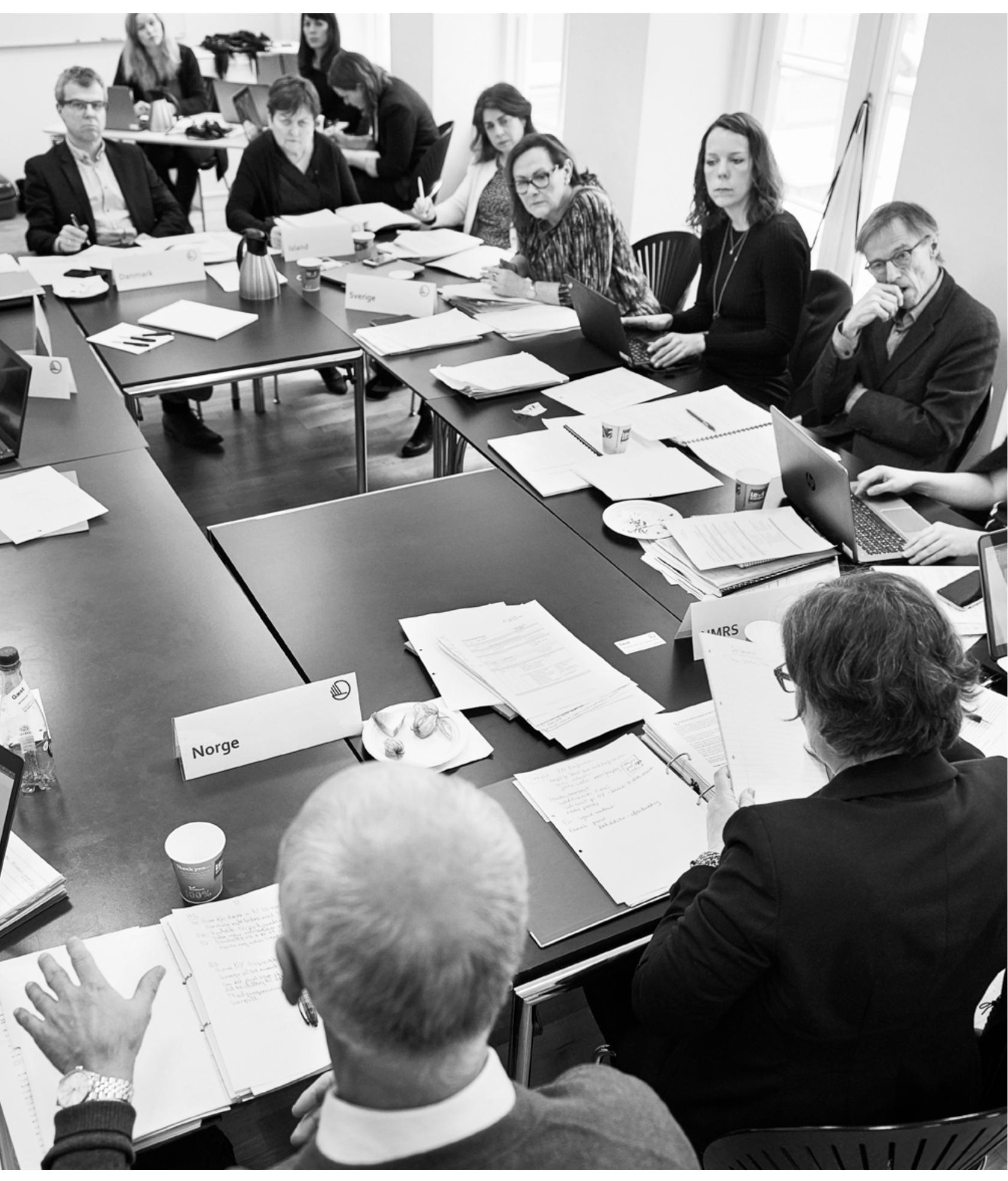




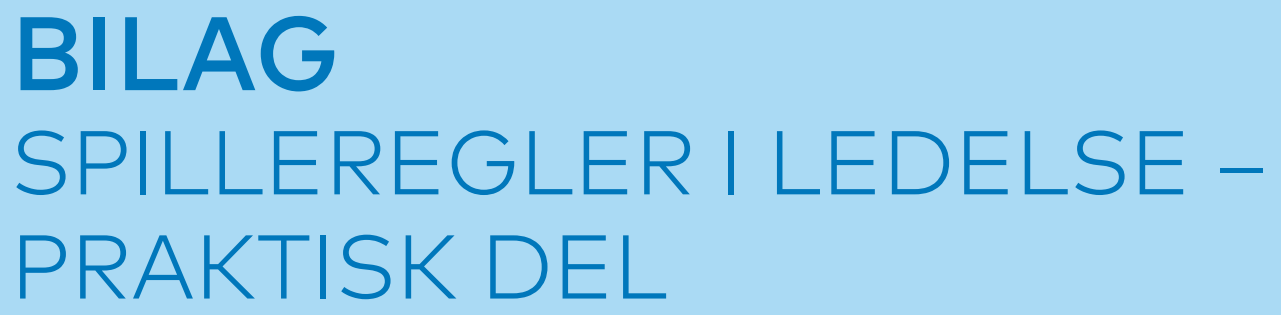

\section{Lederstrukturen i Nordisk ministerråd}

Generalsekretæren er virksomhetens øverste leder. Alle fullmakter utgår fra han eller henne til neste ledernivå, som er lederne i NMRS, kontorsjefene og institusjonssjefene. Dette ledernivået rapporterer direkte til generalsekretæren, som også utøver sin ledelse gjennom disse lederne.

Nordisk ministerråds administrative oppbygning beskriver de formelle ansvars- og myndighetslinjene. En linjeleder i Nordisk ministerråds sekretariat, kontorsjefer og institusjonssjefer er ansvarlige overfor generalsekretæren og har instruksjonsmyndighet overfor medarbeidere i linjen under seg. I bunnen av all ledelse er det viktig at det er tydelig hvem som har linjeansvaret, og hva det ansvaret innebærer. Det vises for øvrig til gjeldende organisasjonsstruktur og den ansvarsfordelingen som framgår av denne samt i delegasjonsreglement.

\section{Lederrollene}

Alle ledere og ansatte på alle nivåer oppmuntres til å kommunisere, koordinere og arbeide på tvers av fagfelt, områder og enheter. Denne friheten betyr imidlertid ikke at det er fritt fram for å inngå avtaler, utøve autoritet eller pålegge ansvar utenom linjen. Kommer slike spørsmål opp, er det viktig at informasjon blir gitt, og at de nødvendige beslutningene treffes i linjen. Man må ikke sette andre i et ansvarsforhold som de ikke kjenner til. Ved slike arbeidsformer er det viktig at ressursbruken og ansvarsfordelingen klargjøres/tydeliggjøres og eventuelt avtales mellom de involverte lederne.

I tillegg til ansvaret for eget område har lederne også et spesielt ansvar for å levere ved sektorovergripende innsatser.

Felles for lederrollene i Nordisk ministerråd er blant annet:

- å utforme mål samt styre etter dem (mål-og resultatoppnåelse)

- å være en pådriver i det nordiske samarbeidet og bidra til konsensusløsninger

- å sikre at sakene behandles og fullføres med høy kvalitet og transparens

- å sikre god ressursstyring med nødvendig fokus på kontroll og oppfølging

- å sikre optimal organisering, koordinering og prioritering

- å håndtere problemer og konflikter 
- å oppnå resultater sammen med og gjennom sine medarbeidere samt betjene oppdragsgivere og brukere

- å motivere, veilede og lede sine medarbeidere

- å være utadvendt, synlig, sikker, reflektert og konsekvent i sin lederatferd

- å ha et kontinuerlig fokus på forbedringer, utvikling, erfaringsbasert læring, effektivisering og modernisering

- å være tydelig, direkte og ærlig og dermed bidra til en konstruktiv tilbakemeldingskultur

- å bidra til likestilling og mangfold i organisasjonen

- å arbeide aktivt for å motvirke kritikkverdig og krenkende atferd.

\section{Den utvidede ledergruppen}

Den utvidede ledergruppen har til hensikt, gjennom en tett dialog mellom ledere i Nordisk ministerråd, å styrke grunnlaget for en målrettet innsats når det gjelder de politiske målene som er satt for det nordiske samarbeidet, og samtidig skape et sterkere fundament for å støtte opp under og utvikle nye politiske mål.
Den utvidede ledergruppen består av ministerrådssekretariatets ledergruppe, kontorsjefene og institusjonssjefene og samles minst to ganger per år.

Den utvidede ledergruppen skal også bidra til å skape nettverk der det gis mulighet for blant annet å diskutere hvordan de politiske målene kan nås, utvikling av nye innsatsområder og ledelses- og organisasjonsutvikling.

\section{Ledergruppen ved NMRS}

Ministerrådssekretariatets ledergruppe skal fungere som en enhetlig ledelse med felles mål og felles ansvar for overordnede beslutninger. I ledergruppen gjelder også linjeansvaret, men den enkelte deltaker deltar ikke utelukkende som representant for sin avdeling. Et helhetlig lederperspektiv betyr blant annet at ledergruppen møtes som hele organisasjonens ledergruppe, og ikke som en gruppe med enkeltledere. Ledere prioriterer møter i ledergruppen og er ansvarlige for at viktige saker blir drøftet med den kvalitet for forutgående saksbehandling som er nødvendig. Lederne skal også sikre at de på annen måte enn på ledergruppemøtene holder kollegaene informert om saker slik at alle har tilstrekkelig informasjon for å utøve helhetlig ledelse. 
Det skal være rom for å ta opp alle aspekter ved ledelse i ledergruppen, men det påligger alle et spesielt ansvar for i hovedsak å ha fokus på organisasjonens mål og hovedoppgaver, på strategiske spørsmål samt på politikkutvikling og initiativer.

Det fattes ikke beslutninger i ledergruppen som sådan, men beslutninger drøftes og forankres. Når saker sendes til ledergruppen for beslutning, ligger beslutningsansvaret formelt sett hos generalsekretæren. Den enkelte leder kan imidlertid også sende saker til ledergruppen for drøfting/konsultasjon der vedkommende selv senere skal fatte beslutning, eller som en del av saksbehandlingen fram til saken sendes videre til generalsekretæren for beslutning.

Linjelederne skal kontinuerlig forsikre seg om at de holder generalsekretæren informert og involvert uten at dette skal medføre at man skyver ansvaret fra seg. Det vises for øvrig til delegasjonsreglementet.

\section{Samarbeidet med personal- organisasjoner}

Samarbeidet med personalorganisasjoner skal bygge på gjensidig respekt og tillit. Dialogen skal være åpen og sikre at personalet gis en reell medbestemmelse i spørsmål som berører dem på deres arbeidsplass.

\section{Hvordan plattformen bør brukes}

Lederplattformen er et styrende dokument som angir innstilling og viljeretning for ledelse i organisasjonen. Plattformen skal være veiledende ved beslutninger og styring og gjøre det lettere å arbeide samordnet.

Lederplattformen bør diskuteres fortløpende i så vel NMRS' ledergruppe som i den utvidede ledergruppen. Den bør være et utgangspunkt for utforming av kravprofiler ved rekruttering av ledere og gjennomsyre intervjuene. Videre bør lederplattformen være et utgangspunkt ved medarbeidersamtalene. Hvordan lederplattformen etterleves, kan også følges opp i medarbeiderundersøkelser. 


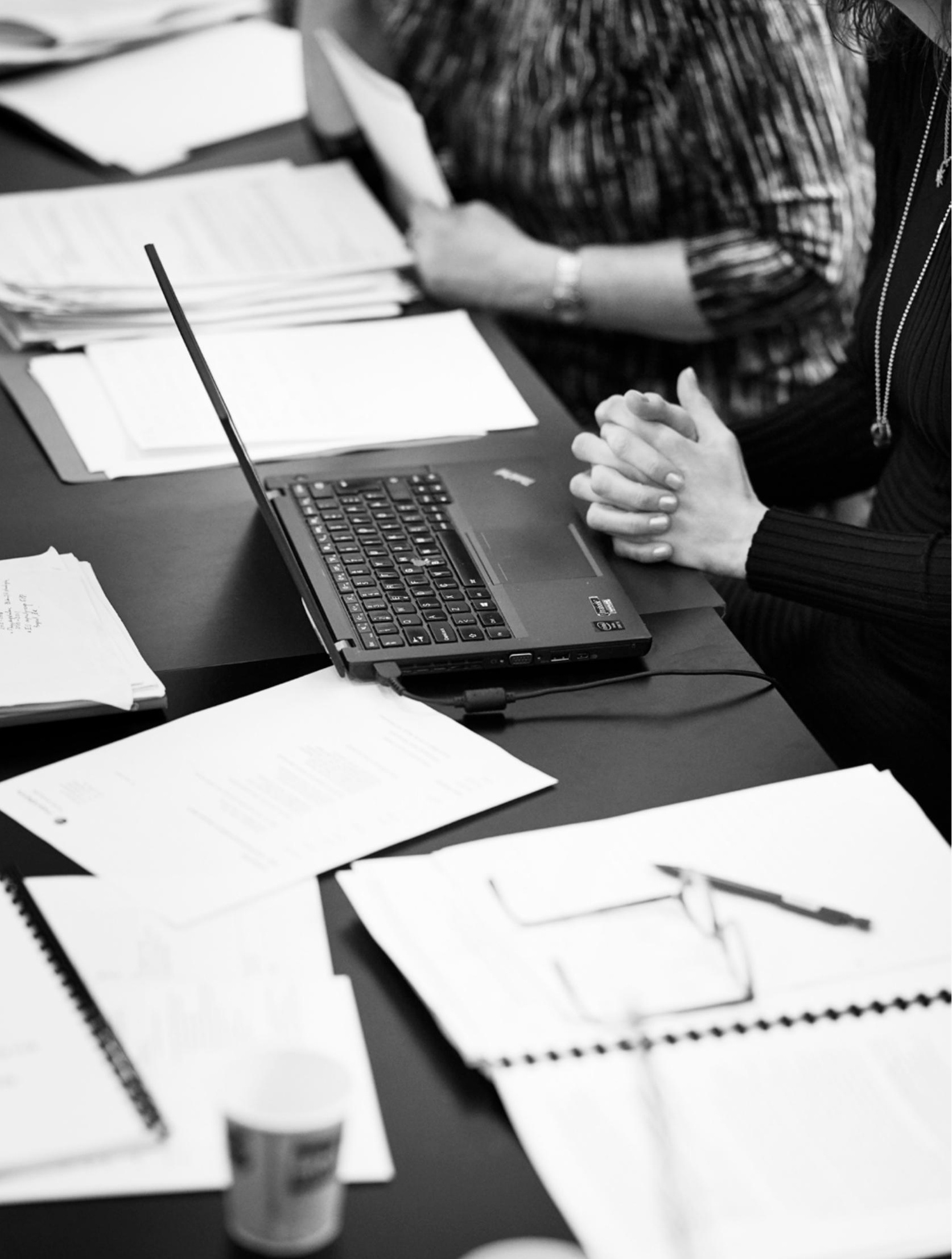




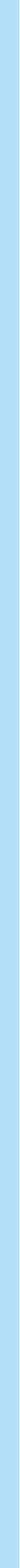




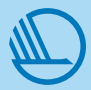

Nordisk ministerråd

Ved Stranden 18

DK-1061 København K

www.norden.org

ANP 2017:710

ISBN 978-92-893-4865-2 (PRINT)

ISBN 978-92-893-4866-9 (PDF) 